\title{
Fish passage system in an irrigation dam (Pilcomayo River basin): When engineering designs do not match ecohydraulic criteria
}

\author{
Claudio R. M. Baigún' ${ }^{1}$, John M. Nestler ${ }^{2}$, Priscilla Minotti ${ }^{3}$ and Norberto Oldani ${ }^{4}$
}

The Route 28 Dam has the potential to block fish movements from La Estrella marsh to the Pilcomayo River. In addition, the many fish that concentrate immediately downstream of the dam may suffer high mortality when they are stranded during low water periods. The goals of this study are to determine if fish are able to pass the spillway and to assess if the design of the installed ladders (pool and weir type) effectively supports upstream migration of Prochilodus lineatus (sábalo). Results showed that only fish longer than $39 \mathrm{~cm}$ should be able to ascend the spillway chute, but when water levels on the spillway crest are over $0.4 \mathrm{~m}$. Fish are also unable to jump from spillway toe to spillway crest because the downstream dissipation pool does not meet the minimum depth criterion for fish to accelerate to sufficient velocity. Fish ladders have insufficient number of pools and some pool dimensions and designs depart from accepted standard designs. Volumetric dissipation power in the upper pool of each fish ladder is too low for fish to rest. Also, attraction flows relative to total spillway discharge at the entrance to each fishway are insufficient. Fish passage failures of both the spillway and pool and weir systems in La Estrella marsh can be traced to the "salmon-centric" concept used by the designers. We conclude that the Route 28 Dam design including its fish passage systems, do not follow criteria to cope with the strong hydrological variability and bioecological characteristics of fish inhabiting pulsatile systems such as La Estrella marsh.

La represa de la ruta 28 posee el potencial de bloquear el desplazamiento del sábalo (Prochilodus lineatus) desde el bañado La Estrella hacia el río Pilcomayo. Adicionalmente los numerosos peces que se concentran aguas abajo de la represa pueden sufrir una alta mortalidad cuando quedan atrapados durante el período de aguas bajas. Los objetivos de este estudio son determinar si los peces son capaces de superar el vertedero y evaluar si el diseño de los pasos para peces del tipo tanqueescalón ya instalados es adecuado para facilitar la migración hacia aguas arriba. Los resultados muestran que solo aquellos peces mayores a $39 \mathrm{~cm}$ de longitud total son capaces de ascender la pendiente del vertedero, pero únicamente cuando el nivel del agua en la cresta alcanza o supera los $40 \mathrm{~cm}$. Los peces son incapaces de saltar desde el pie del vertedero hasta la cresta debido a que la pileta de disipación no sigue los criterios de mínima profundidad requeridos para alcanzar la suficiente velocidad y altura. Asimismo, los pasos para peces no poseen el número suficiente de tanques y algunas de sus dimensiones y su diseño se apartan de los estándares aceptados. La potencia de disipación volumétrica en el tanque superior de cada paso es inadecuada para que los peces puedan descansar, mientras que los flujos de atracción relativos a la descarga del vertedero resultan insuficientes. La baja eficiencia del vertedero y de los sistemas de pasos para peces pueden ser adjudicados a un concepto de construcción orientado a salmónidos. Concluimos que la represa de la ruta 28, incluyendo sus sistemas de pasaje para peces, no siguen los criterios adecuados para hacer frente a alta variabilidad hidrológica y las características bioecológica de los peces que habitan en bañados pulsátiles como La Estrella.

Key words: Dam spillway, La Estrella marsh, Pilcomayo basin, Pool and weir system.

\section{Introduction}

Many dams augment water supply in South America wherever topography and river flow are suitable. Dam environmental impacts are increasingly an important issue
(Marmulla, 2001) because they fragment the landscape (Agostinho et al., 2003, Fernández et al., 2007), modify flood pulses (Oldani et al., 2004, 2007) and block migratory movements (Larinier, 2001; Baigún et al., 2011). Unfortunately, most dams still lack fish passage systems (Quirós, 1989;

${ }^{1}$ Instituto Tecnológico de Chascomús, (IIB-INTECH), Camino de Circunvalación Laguna, Km 6, 7120 Chascomús, Argentina. cbaigun@gmail.com

${ }^{2}$ IIHR - Hydroscience \& Engineering, University of Iowa, 100 Stanley Hydraulics Laboratory, Iowa City, IA $52242-1585$ USA. John.M.Nestler@gmail.com

${ }^{3}$ Universidad Nacional de San Martín, Peatonal Belgrano 3563, piso 1, (1650) Gral. San Martín, Argentina. priscilla.minotti@gmail.com ${ }^{4}$ Instituto de Desarrollo Tecnológico para la Industria Química (INTEC-CONICET-UNL), Güemes 3450, S3000 Santa Fe, Argentina. gbio@ceride.gov.ar. 
Agostinho et al., 2002) except at hydroelectric dams. Even these systems have either ignored or underestimated the need to adapt designs to meet the behavioral characteristics and swimming requirements of neotropical fish faunas (Agostinho et al., 2007a; Oldani et al., 2007). The most common fish passage systems installed in South America are of the pool and weir types (ladders) originally developed to pass salmonids and clupeids in northern hemisphere rivers (Clay, 1995; Larinier, 2001). Godoy (1985) mentioned that more than 20 pool and weir systems in northern Brazilian dams were constructed to pass different species such as Prochilodus scrofa, Leporinus copelandii, L. octofasciatus, L. elongatus, Salminus brasiliensis, S. hillari and Pimelodus clarias. According to Agostinho et al. (2007b) such systems are suitable for low head dams less than $16 \mathrm{~m}$ and Baigún et al. (2011) noted that they are mostly avoided by large migratory bottom species.

In Argentina only two examples of pool and weir systems are known. The first is the Carcaraña Dam (Santa Fe Province) which historically passed Prochilodus lineatus (sábalo) and Salminus brasiliensis (Bonetto et al., 1971). The second is the Route 28 Dam so called because the roadway runs across a low-head dam and spillway crossing the marsh from north to south. The construction of the Route 28 Dam created considerable controversy because it was thought that the dam could block sábalo migration between La Estrella marsh and the Pilcomayo River. There was concern that the blockage would prevent fish from completing their spawning movements and result in high mortality as fish became stranded downstream during low water periods impacting negatively on the important sábalo fisheries in the upper Pilcomayo basin (Motchek et al., 1995).

Surprisingly, the performance of the fish passage system at the Route 28 Dam has never been assessed so that its adequacy to mitigate the impacts of the dam is unknown. The lack of assessment is important because this fish passage system is one of many low head dams that either have been recently constructed or are planned for agricultural regions of Argentina and neighboring countries. Information obtained by assessing the overall performance of the fish passage system and by relating the effects of specific design elements are important to ensure environmentally sustainable water resources development through effective mitigation and wise natural resource management. Thus, the goals of this study are to determine for the first time if fish are able to pass the spillway of the Route 28 Dam and to assess if the design of the pool and weir fishways effectively supports upstream migration of sábalo.

\section{Material and Methods}

The Route 28 Dam is located in Formosa Province (Argentina) on the east side of La Estrella marsh in the Pilcomayo River basin (Fig. 1). The elevation of the Route 28 Dam was progressively increased from 1993 to 2003 to assure an all-season crossing for Route 28 over the La Estrella marsh thereby permanently connecting the northern and southern parts of the province and to provide water for land irrigation. Water regulation structures involve a main free over fall type spillway and two gated outlets functioning as secondary controlled spillways. One of this controlled spillway is located close to the main spillway and the other $6 \mathrm{~km}$ to the south on the Salado River channel. The main spillway is $800 \mathrm{~m}$ long and features three fish passage systems of the pool and weir type, located at the middle and at each end of the spillway.

Like other marshes located on the Chaco plain, La Estrella is a highly seasonal environment with substantial differences between dry and wet seasons. Water level within the marsh is directed tied to the discharge of the inflowing Pilcomayo River (Guinzburg et al., 2005). The hydrological cycle is characterized by heavy rain falls in the upper basin (Bolivia) from November to April and by local precipitation that peaks from October to March. From middle the summer to fall La Estrella marsh is totally inundated by flows from the Pilcomayo River forming a large wetland that expands laterally as water runs from west to east across the marsh. After the route was elevated forming the dam, the marsh upstream of the dam became permanently flooded even during the dry season.

The study area was visited in March and April 2008, September 2009, and March 2010 to describe fish movements in the vicinity of the primary and secondary spillway areas and at fish ladders under different hydrological conditions. At each visit, when hydrological conditions allowed, visual counts of fish attempting to ascend the spillways or pass through the pool and weir systems were recorded. Twenty local artisanal fishermen who permanently live and fish around the marsh were interviewed to obtain information about fish movements in the main spillway area. Total length distributions were obtained from fish collected at the tailwater using gillnets. Water temperature, dissolved oxygen concentration, conductivity, and $\mathrm{pH}$ were recorded with a Lutron IK 2001 on digital probe.

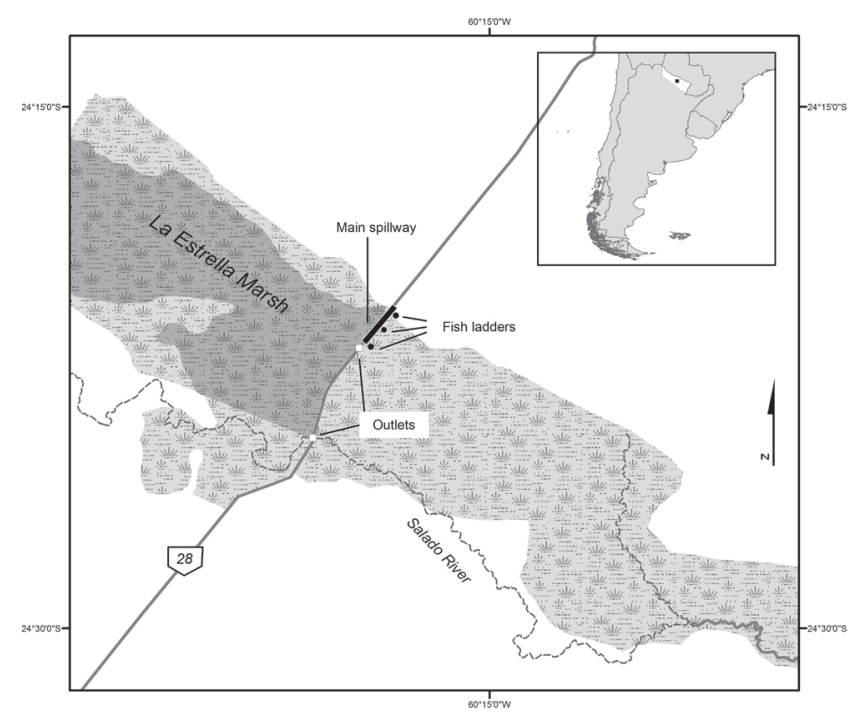

Fig.1. Location of La Estrella marsh- Route 28 Dam complex in Formosa Province, Argentina. 
Long term specific hydrologic data for the Route 28 Dam describing water surface elevations are unavailable. Based on our periodic observations, La Estrella marsh floods between February to June with the duration of flooding dependent on regional climate patterns. We felt that measurements made during this critical period would provide the greatest information relating hydrologic and hydraulic conditions to fishways performance. For safety reasons and ease of access, morphometric measurements of the fish ladders and main spillway were made during the spring low water period. These measurements are used to describe important design parameters that could then be compared to accepted guidelines. The following formulas were employed to develop design parameters for an ogee crest uncontrolled flow spillway and pool and weir fishway.

\section{Spillway characteristics}

a) Discharge (Q) over the spillway in $\mathrm{m}^{3} \mathrm{~s}^{-1}$ for a rectangular spillway with wide crest was calculated using the common Francis formula:

$$
\mathrm{Q}=\mathrm{CLH}^{3 / 2}
$$$$
\text { where: }
$$

$\mathrm{L}=$ Length of the spillway in $\mathrm{m}$,

$\mathrm{C}=$ Spillway coefficient considered as 2 and

$\mathrm{H}=$ Water height on the spillway crest (roadbed) in $\mathrm{m}$

b) Water velocity $(\mathrm{V})$ at spillway crest as:

$$
\mathrm{V}=\mathrm{Q} / \mathrm{L} * \mathrm{H}
$$

c) Mean water velocity $(\mathrm{Vp})$ in the spillway chute in $\mathrm{m} \mathrm{s}^{-1}$ was estimated according to Reiser et al. (2006):

$$
\mathrm{Vp}=\frac{\left\{\mathrm{V}^{2}+2 \mathrm{~g}[\mathrm{Ls} \sin (\mathrm{Sp})-\mathrm{dp}]\right\}^{3 / 2}-\mathrm{V}^{3}}{3 \mathrm{~g}[\mathrm{Ls} \sin (\mathrm{Sp})-\mathrm{dp}]}
$$

where:

Ls $=$ total chute length in meters,

$\mathrm{Sp}=$ chute angle $=25^{\circ}$,

$\mathrm{g}=$ acceleration due to gravity $\left(9.8 \mathrm{~m} / \mathrm{s}^{2}\right)$, and

$\mathrm{dp}=$ water depth at the tailrace in $\mathrm{m}$.

d) Water level (Ws) in the chute in $\mathrm{m}$ as

$$
\mathrm{Ws}=\mathrm{H} / \mathrm{Vp}
$$

\section{Fishway characteristics}

Each fishway is comprised of three rectangular pools. The upper pool is an extension of the spillway crest so that water can overflow directly into this pool. Total discharge from upper pool is greater than discharge of the middle and lower pool. Consequently, a different equation is needed to estimate flow into the middle and lower pools versus the upper pool. Important hydraulic characteristics of the fishways are calculated as follows.

a) Flow discharge $(\mathrm{Q})$ in the middle and lower pools of the ladders in $\mathrm{m}^{3} / \mathrm{s}$ is estimated (Larinier, 2002c) as:

$$
\mathrm{Q}=\mathrm{Cd} \mathrm{b}(2 \mathrm{~g})^{0.5} \mathrm{H} 1^{1.5}
$$

where:

$\mathrm{Q}=$ flow discharge $\left(\mathrm{m}^{3} / \mathrm{s}\right)$,

$\mathrm{Cd}=$ discharge coefficient $(0.4)$

$\mathrm{b}=$ width of the notch in $\mathrm{m}$, and

$\mathrm{H} 1=$ depth of the notch in $\mathrm{m}$.

Flow into the upper pool of the fishway is estimated using equation (5), but parameterized using information from spillway characteristics.

b) Volumetric dissipated power (Pv) at each pool in watts $/ \mathrm{m}^{3}$ is estimated (Larinier, 2002c) as:

$$
\mathrm{PV}=\rho g \frac{\mathrm{Q} \triangle \mathrm{h}}{\mathrm{V}}
$$

where:

$\rho=$ density of water $\left(1000 \mathrm{~kg} / \mathrm{m}^{3}\right)$,

$\triangle \mathrm{h}=$ head differences between pools $(\mathrm{m})$, and

$\mathrm{V}=$ volume of water in the pool $\left(\mathrm{m}^{3}\right)$

c) Optimum length of pools (L) is estimated as 12 times $\mathrm{h}$ $(12 * \mathrm{~h})$ (Larinier, 2002c) with $\mathrm{h}$ defined as the distance from the bottom of the pool to the top of the notch.

d) The number of pools $(\mathrm{N})$ required for the spillway height is determined (Larinier, 2002c) as:

$$
\mathrm{N}=\frac{\text { htot }-1}{\triangle \mathrm{h}}
$$

where:

htot $=$ total height computed as the difference between the spillway crest and tailwater

e) Maximum flow velocity created by the lower pool into the tailrace is estimated (Larinier, 2002c) as:

$$
\mathrm{V}=(2 \mathrm{~g} \triangle \mathrm{H})^{0.5}
$$

where:

$\triangle \mathrm{H}=$ head difference between lower pool and tailrace

\section{Fish swimming capabilities}

Burst speed and endurance time are estimated for fish ranging from 25 - to $45-\mathrm{cm}$ in total length using the nomograms developed by Beach (1984) assuming a water temperature of $25^{\circ} \mathrm{C}$. Burst swimming speed represents the highest speed that can be maintained for short periods using anaerobic metabolism (Beamish, 1978).

a) Maximum distance that fish could swim on the spillway chute against different water velocities (D) is calculated by the biocinetic equation of Katopodis (1992) as:

$$
\begin{aligned}
& \mathrm{D}=(\mathrm{Vf}-\mathrm{Uw}) \mathrm{t} \\
& \text { where: } \\
& \mathrm{Vf}=\text { fish maximum speed } \\
& \mathrm{Uw}=\text { water velocity } \\
& \mathrm{t}=\text { travel time at maximum speed }
\end{aligned}
$$

b) The capacity of fish to leap from one pool to another is determined from the trajectory equations of Larinier (2002d) 
both for maximum horizontal distance (Xmax) and maximum height (Ymax) as:

$$
\begin{aligned}
& X \max =\frac{V_{o^{2} \cos \beta \sin \beta}}{g} \\
& Y \max =\frac{\left(V_{0} \sin \beta\right)^{2}}{2 g}
\end{aligned}
$$

where:

$\beta=$ initial leaping angle measured from the horizontal and

$\mathrm{Vo}=$ speed of the fish as it exits the water (assumed to equal maximum burst velocity).

\section{Results}

Fish movement patterns and demographic characteristics

Interview results from artisanal fishermen that regularly fish in the Route 28 Dam area indicated that most of them $(83 \%)$ considered that downstream fish movements were strongly correlated to periods of flooding. At the main spillway, they were able to catch fish by "snagging" (quickly pulling hooks through the water) thus confirming that fish pass over the route during the flood season. Fishermen also suggested that the critical limiting period for upstream passage occurs when the water level over the spillway crest drops below 0.5 $\mathrm{m}$. During the fall and winter the senior author observed that fish were attracted to the spillway as water levels decreased in the tailwater. Those unable to escape upstream died as water evaporated or were eaten by alligators and birds. Results derived from interviews with fishermen suggest that major fish concentrations in the main spillway tailrace are related to marsh hydrologic regime. We propose that during the flooding period in summer juveniles drift downstream and adults are able to cross over the roadbed and disperse into La Estrella marsh which ultimately connects downstream with the Salado River. However, during the fall and winter as the seasonal flood pulse ends and water levels decrease these areas begin to dry out stranding fish in small lagoons where they are preyed upon by birds (Ardea albai, Ciconia maguari, Jabiru mycteria and Mycteria americana) and alligators (Caiman yacare) and also harvested by local fishermen. Fish also try to escape upstream as they detect reduced water levels by attempting to ascend the main spillway or the pool and weir systems installed on the main spillway. These behaviors observed by fishermen are in agreement with data derived from recently completed tagging experiments in the marsh (Baigún pers.comm.) and previous studies (Bayley, 1973; Smolders et al., 2000). A similar pattern was noted for the gated outlet located at the Salado River were fish were unable to ascend and either remained in the river or migrated downstream. All evidences indicate that adult sábalo that entered into the marsh during flood season, even surpassing the Route 28, attempt to leave the marsh as water recedes during the fall and beginning of winter and migrated upstream to the Pilcomayo River through a network of small marshes and creeks interconnected during high flow periods.

Fish sampled in March and April of 2008 using gillnets and a beach seine in the Route 28 area ranged in total length from 26 - to $45-\mathrm{cm}$ with a mode of $32-\mathrm{cm}$ corresponding to a body depth of 10-cm (Fig. 2).

\section{Structural and hydrological characteristics}

At the primary spillway water is discharged over an uncontrolled $0.8-\mathrm{km}$ long main spillway having a $6.7-\mathrm{m}$ wide crest and $1.6-\mathrm{m}$ height that is typically active only during the summer flooding period (Fig. 3a). The spillway chute has $25^{\circ}$ slope and $3.7-\mathrm{m}$ length and terminates at a $0.3-\mathrm{m}$ long flat apron. The apron ends at a $0.5-\mathrm{m}$ deep and 4.0-m wide stilling basin. Measured water velocities on the spillway crest ranged from 0.63 to $1.41 \mathrm{~m} /$ $\mathrm{s}$ being flow supercritical, and measured water levels on the chute vary from 0.05 to $0.15 \mathrm{~m}$. Hydraulic characteristics varied among pools in the three fishways because of small differences in notch height, volume, and bottom profile (Fig. 3b, c), departing in some cases from standard guidelines (Table 1). Estimated attraction flow at the entrance of each fishway is calculated as $0.22 \mathrm{~m}^{3} / \mathrm{s}$ for a drop of $0.3 \mathrm{~m}$, which when summed represents only $0.16 \%$ of the average spillway discharge $\left(404 \mathrm{~m}^{3} / \mathrm{s}\right.$ at a crest depth of $0.4 \mathrm{~m}$ ). The maximum velocity of the flow created by the lower pool drop depends on the tailrace water level, which ranged from $1.9 \mathrm{~m} / \mathrm{s}$ for (drop of $0.2 \mathrm{~m}$ ) to $2.8 \mathrm{~m} / \mathrm{s}$ (drop of $0.4 \mathrm{~m}$ ). The upper pool Pv exceeded the threshold value of 150 watts $/ \mathrm{m} 3$ recommended for non salmonid species (Larinier, 2002a) when water depth over the spillway crest exceeded $0.2 \mathrm{~m}$. To avoid such limitation the upper pool volume should be tripled. Clay (1995) recommends minimum pool dimensions of $2.4 \times 3 \times 1.2 \mathrm{~m}(8.6$ $\mathrm{m}^{3}$ ). For Brazilian ladders, Martins (2005) noted that $\mathrm{Pv}$ ranged between 123 to $294 \mathrm{~W} / \mathrm{m}^{3}$ for pools longer (3-5 m), deeper (1.5 to 2.35 ) and with higher volume (12 to $\left.52 \mathrm{~m}^{3}\right)$ than those installed in the Route 28 Dam.

No fish were observed using the pool and weir systems under the different flow conditions occurring during field surveys. At the main spillway we observed $83 \%$ of the fish reaching the middle of the chute swept back to the tailrace. We did not observe any fish passing the secondary spillway.

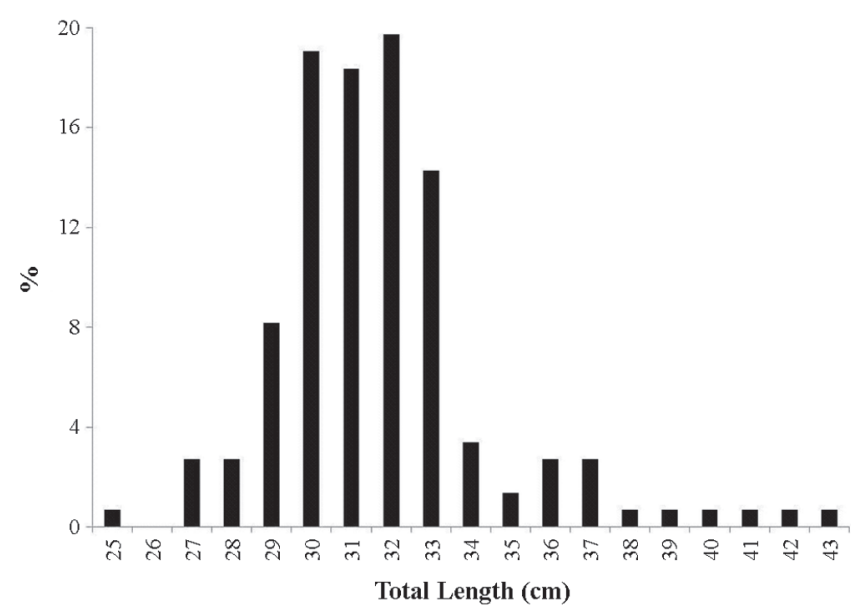

Fig. 2. Length distribution of Prochilodus lineatus captured in the Route 28 Dam. 

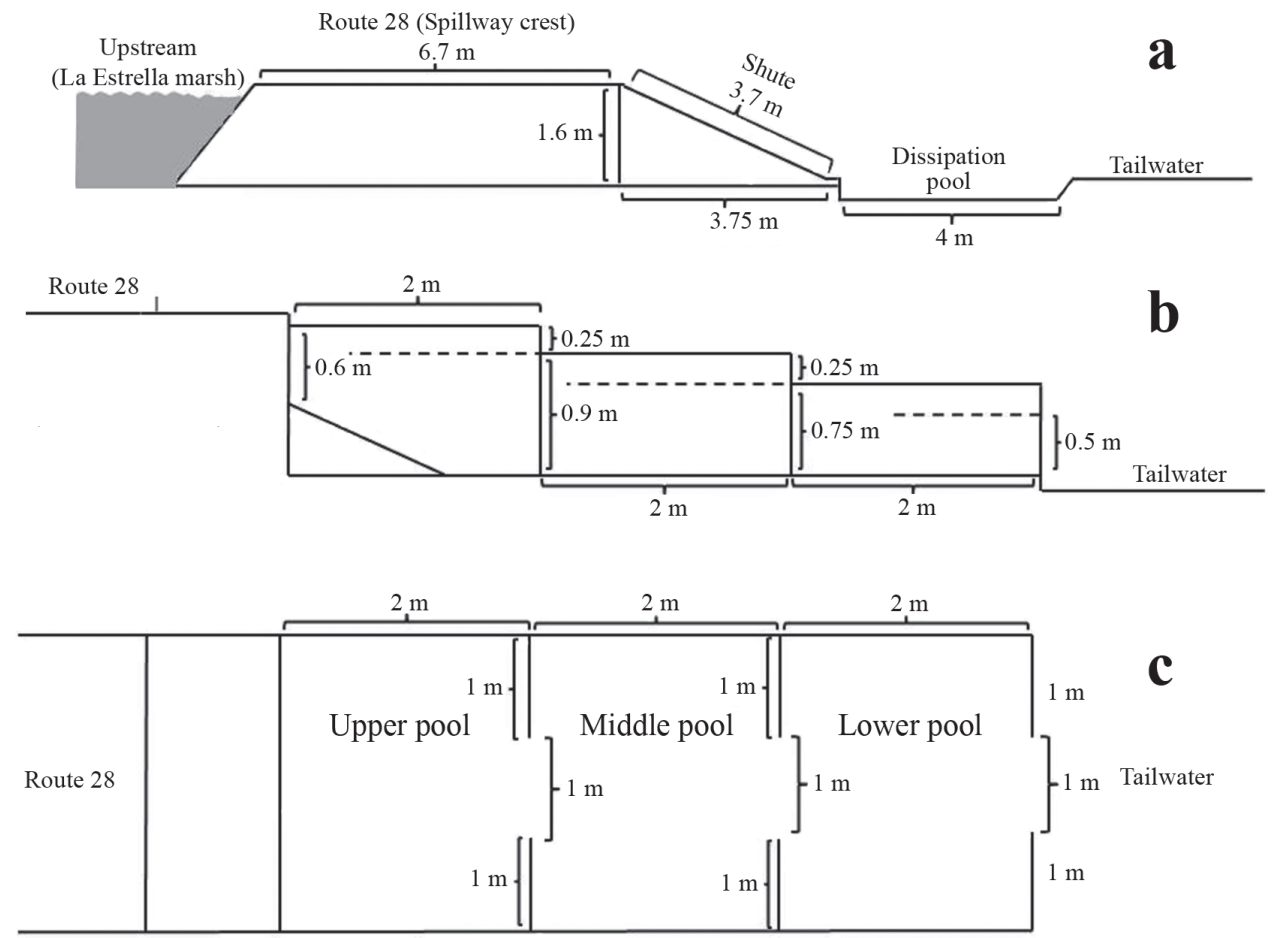

Fig. 3. View of spillway (a) and pools and weir systems (b, c) design.

Table 1. General characteristics of pool and weir systems at the Route 28 dam and comparison with guidelines for standard systems. ${ }^{a}$ Estimated for a water level of $20 \mathrm{~cm}$ over the crest.

\begin{tabular}{|c|c|c|c|c|c|}
\hline Parameter & $\begin{array}{l}\text { Upper } \\
\text { pool }\end{array}$ & $\begin{array}{c}\text { Middle } \\
\text { pool }\end{array}$ & $\begin{array}{c}\text { Lower } \\
\text { pool }\end{array}$ & $\begin{array}{c}\text { Total } \\
\text { system }\end{array}$ & $\begin{array}{l}\text { Standard } \\
\text { guidelines }\end{array}$ \\
\hline Length (m) & 2 & 2 & 2 & 6 & $1.75-3$ \\
\hline Width (m) & 3 & 3 & 3 & & \\
\hline Depth (m) & 0.90 & 0.75 & 0.50 & & $0.6-1$ \\
\hline Volume $\left(\mathrm{m}^{3}\right)$ & 3.5 & 5.4 & 4.2 & 13.1 & \\
\hline Pool drop & $\begin{array}{c}0.25 \\
\text { (from crest) }\end{array}$ & $\begin{array}{l}0.25 \\
\text { (from upper pool) }\end{array}$ & $\begin{array}{c}0.25 \\
\text { (from middle pool) }\end{array}$ & & $0.20-0.3$ \\
\hline Pool depth/pool drop ratio & & 3 & 2 & & 1.2 to 1.4 \\
\hline Notch width (m) & 1 & 1 & 1 & & 0.2 to 0.4 \\
\hline Notch surface $\left(\mathrm{m}^{2}\right)$ & 0.25 & 0.25 & 0.25 & & 0.04 to 0.10 \\
\hline System slope & & & & $19^{\circ} ; 1: 4$ & $5-10 ; 1: 7$ to $1: 12$ \\
\hline Number of expected pools & & & & & 8 \\
\hline Flow discharge $\left(\mathrm{m}^{3} / \mathrm{s}\right)$ & $0.23^{\mathrm{a}}$ & 0.19 & 0.19 & & \\
\hline Attraction flow/spillway flow ratio & & & & & 1 to $5 \%$ \\
\hline $\begin{array}{l}\text { Volumetric dissipated power } \\
\left(\mathrm{watt} / \mathrm{m}^{3}\right)\end{array}$ & $374^{\mathrm{a}}$ & 79 & 76 & & 150 \\
\hline
\end{tabular}

\section{Fish swimming capabilities}

We calculate that fish shorter $30 \mathrm{~cm}$ will be unable to ascend the spillway because their burst speed is lower than measured water velocity $(4.9 \mathrm{~m} / \mathrm{s})$ of the chute (area A of Fig.4). Fish between 30 and $39 \mathrm{~cm}$ total length, despite having a higher burst speed, could also not ascend the spillway because they cannot sustain sufficient speed along the chute length (Area B, Fig. 4). Only fish longer than $39 \mathrm{~cm}$ matched both criteria (Area C, Fig. 4) and thus should be able to ascend the spillway chute at velocity of $4.88 \mathrm{~m} / \mathrm{s}$. However fish this size have a body depth greater than the $10 \mathrm{~cm}$ water depth of the chute. Water depth in the chute decreases to less than $10 \mathrm{~cm}$ as water levels on the spillway crest decrease to $0.4 \mathrm{~m}$. The minimum chute depth required for passage should be between 0.5-1 times fish body depth (Reiser et al., 2006).

On the other hand, the fish leaping analysis indicates that a $32-\mathrm{cm}$ fish cannot ascend the spillway because its maximum leaping height and maximum leaping distance are both less than the height and length of the spillway chute, respectively (Fig. 5).

\section{Discussion}

The Route 28 Dam is typical of many low-head dams in South America that could block the movement corridor of migratory 


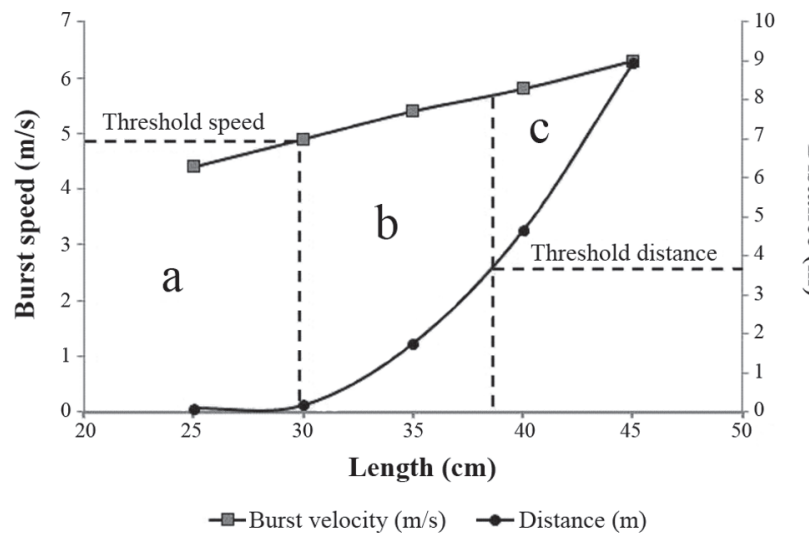

Fig. 4. Relationship between fish total length and burst speed and maximum distance that fish can swim.

fishes. This study is the first description and analysis of such a dam in Argentina and the results should have wide application to the many similar dams in the region. In this study we focus on sábalo due to its socioeconomic importance although many other species face similar problems of seasonal habitat fragmentation. Our evaluation is based on a simple quantitative analysis of the general hydrological and structural characteristics of installed fish passage facilities contrasted with fish swimming capabilities.

We identified several shortcoming of spillway and the pool and weir fishway design related to both structural and hydrological factors. The spillway slope creates supercritical flow conditions $(\mathrm{F}>1)$ that are both too fast and too shallow for fish passage. According to Webb et al. (1991) swimming efficiency reduces by $30-50 \%$ when water depth is less than body depth, and based on the biocinetic equation (Katopodis, 1992) only fish long and fast enough to swim up the chute could ascend to the crest. However they violate the body depth criterion and fish of the correct body depth violate the swim speed criterion. Since most of fish attempting to ascend the spillway are between 32 and $35 \mathrm{~cm}$, such limitation explains why such a small proportion of fish were observed to pass the site. Without question, long spillways with high slope chutes are effective fish passage barriers. The dissipation pool at tailrace also does not meet the minimum depth criteria required for fish to jump to the height of the spillway. As noted by Powers \& Osborn (1985) if the tailrace is too shallow downstream of the chute, then critical velocities will extend onto the dissipation pool until water velocity slows sufficiently for a hydraulic jump to form. These high water velocities will limit the distance which fish can jump. Also, the water velocity at the waterfall crest (the landing area of a leaping fish) must be less than the fish's burst speed and water depth must be greater than the depth of the fish body depth for effective swimming. A successful leap would require that a jumping sábalo would have to emerge from the water at a longitudinal distance of 1.15 $\mathrm{m}$ from the spillway crest, a physical impossibility with the present spillway configuration. Additionally, turbulent flow (Reynolds number $>500$ ) entrains air bubbles which reduces

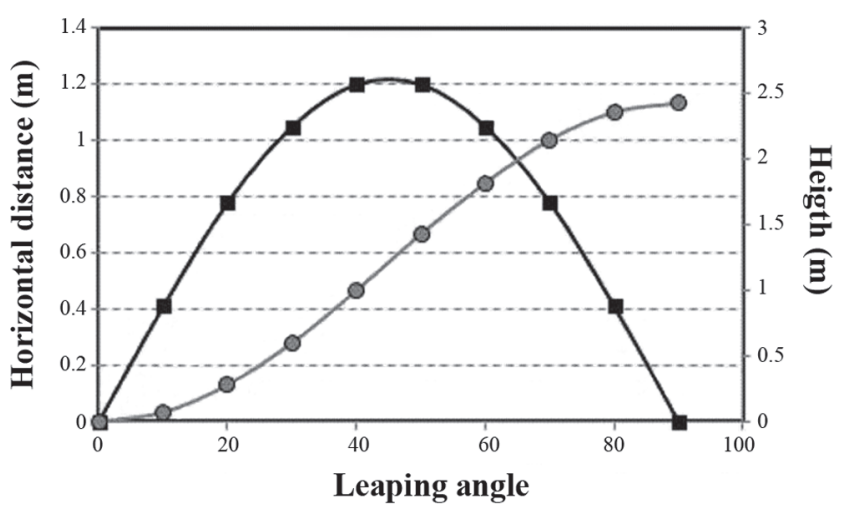

Fig. 5. Maximum horizontal distance (black line and squares) and maximum height (grey line and dots) reached by a fish with modal length of $32 \mathrm{~cm}$, estimated for different leaping angles.

water density and further reduces fish capacity for leaping. Powell \& Orsborn (1985) recommended that depth of the dissipation pool should be greater than the height of the spillway above the dissipation pool water surface to minimize entrained air from reaching the bottom of the dissipation pool. A dissipation pool depth of $0.5 \mathrm{~m}$ such as is at the Route 28 Dam appears inappropriate to avoid entrained air in the dissipation pool.

Like almost all fish ladders the performance of the pool and weirs systems at the Route 28 Dam is strongly dependent on water level. During high water we noted that the fishways are completely overflowed and filled with debris whereas in low water period the systems stopped functioning as soon as water stopped overflowing the spillway. The Route 28 Dam ladders did not mitigate for the blockage created by the excessive slope of the spillway and also exhibit several structural problems. There are an insufficient number of pools in the ladders and some pool dimensions departed from accepted standard designs. In addition pool hydraulic conditions are barriers to fish passage because the most upstream pool displayed low capacity for energy dissipation. Volumetric dissipated power is an important hydraulic parameter that prevents a transfer of energy between pools. This parameter also controls turbulence and pool aeration and reflects kinetic energy pattern in the fishway (Tarrade et al., 2008). Importantly, the critical values of dissipated power used in this study were derived for salmonids, because appropriate information for South American fishes is unavailable (Oldani et al., 2007). Measured slope also exceeded standard guidelines and was almost twice that observed for Brazilian ladders (Martins, 2005).

Reduced water velocity at the entrance of the lower pools of each ladder may also limit fish entry. Ideally, attraction water velocity should range between 1 and $2.4 \mathrm{~m} / \mathrm{s}$ (Clay, 1995) or about $60 \%-80 \%$ of fish critical speed (Pavlov, 1989). Such velocity is provided by the lower pool drop with different tailrace water level but despite being within the range $(0.5-2.5 \mathrm{~m} / \mathrm{s})$ suggested by Capeleti and Petrere (2006) for Prochilodus, it is only about half of the maximum velocity estimated at the bottom 
of the spillway chute. It is unlikely that fish can detect this low energy signal in an otherwise high energy background to find the ladder entrance. The combined discharge of the three ladders at the Route 28 Dam is likely insufficient relative to total spillway discharge to be detectable by fish outside of the immediate vicinity of the ladder (Fig. 6). Fish that encounter long spillways like the Route 28 may be unable to detect the entrances of the fish ladders without substantial attracting flows. The attraction flows at the Route 28 Dam fish ladders are far from the $1 \%$ to $5 \%$ of total discharge recommended by Larinier (2002b). Eight ladders of the size presently used at the Route 28 Dam would be required to reach Larinier's $1 \%$ criterion and 40 ladders would be required to meet his $5 \%$ criterion. In addition, and as noted in Figure 6 the turbulent mixing that occurs in the spillway further masks ladder attraction flows, probably compounding negative effects of the small attracting flows.

Clay (1995) recommends for salmonids that fishway entrances should be in close proximity to dam outlets such as draft tubes and spillways. However, salmonids typically inhabit highgradient streams and are suited to navigate through the highly turbulent flows of tailraces to find bypass entrances. La Plata basin rivers have flatter gradients in the lower reaches and fish that evolved in low gradient systems may be unable to locate small attraction flows against a background of high powerhouse and spillway flows (Larinier, 2001). For example, non salmonids species such as sturgeon often accumulate in eddies in tailwaters (Pavlov, 1989) whereas salmon typically are in the high energy flow fields near the dam searching for upstream passage. Similar results for sábalo were observed by Delfino et al. (1986) in the tailrace of Salto Grande Dam where fish congregated in low velocity refuges. Also inadequate attraction flows that are partially masked by turbulence near the powerhouses are thought to account for the low efficiency of elevators installed in Yacyreta (Oldani \& Baigún, 2002; Oldani et al., 2007).

We observed that middle and lower pools had adequate depth at the weir to allow fish to leap into the upper pool. The plunge pool depth was at least 1.25 times the distance of the crest of the waterfall to the water level of the pool (Stuart, 1964 in Bjornn \& Reiser, 1991) or at least equivalent to full body length. However, the upstream side of the upper pool is significantly sloped which physically displaces fish making it impossible for them to leap to the pool crest and then swim across the roadbed. On the other hand, lack of suitable depth in the stilling basin at the ladder entrance might also prevent fish from jumping into the lower pool from the tailrace, particularly as the tailrace depth falls to $25 \mathrm{~cm}$. In addition, pool and weir systems are not self regulating so that the hydraulic characteristics to the upstream entrance change with water elevation.

Passage failures of both the pool and weir systems and spillway in La Estrella marsh can be traced to the design concept that salmonid systems can be used as a template to design passages directly for neotropical species without further modification. This generalization applies also to other more sophisticated passage systems that are used in South America large rivers (Baigún et al., 2007; Agostinho, 2002). Certainly, large migratory fishes of South America exhibit important differences from salmonids because almost all are potadromous, iteroparous (make several spawning migrations during their lifetime) and use floodplains as hatching areas (Oldani \& Baigún, 2002; Oldani et al., 2005). Previous results of ladder performance showed divergent results. Agostinho (2007b) reviewed the functioning of ladders in Brazil and concluded that they were appropriate for dams lower than 16m. Pioneer studies by Godoy $(1957,1975)$ in Cachoeira da Emas demonstrated high efficiency for a 3-m high fish ladder. At Itaipu Dam an experimental ladder of 27-m allowed the entry of a moderate number of species (Fernandez et al., 2004) finding these authors that $41 \%$ of species enter the ladder. Oldani \& Baigún (2002) estimated that Prochilodus lineatus represented less than $2 \%$ of passed fish at Yacyreta Dam (Argentina-Paraguay). On the other hand few migratory species of large size were recorded in the fish ladders at Igarapava Dam (Vono et al., 2004) or Salto Moraes Dam (Godinho et al., 1991). Godinho et al. (1991) noted that in Salto Morais Dam $83 \%$ of species entered the ladders but only $2 \%$ reached the exit. Alves (2007) noted that passage efficiency for tagged fish was lower than 5\% and Prochilodus costatus was one of the few species that ascended the entire length of the ladder. A similar pattern of poor performance was observed by Makrakis et al. (2007) at Engenheiro Sérgio Motta (Porto Primavera) Dam (Brazil) where only $11 \%$ of downstream species passed through the fishway and that Prochilodus exhibited a very low abundance in the system. Britto \& Sirol (2006) reported that Canoas I and II ladders were used by $83 \%$ of downstream species, only $16 \%$ were migratory species, and Prochilodus lineatus was one of the most abundant species. However in Lajeado Dam, even though $62 \%$ of downstream species were detected in the ladder (Agostinho et al., 2007c, 2007d), Prochilodus nigricans, the most important commercial species in the area, accounted for

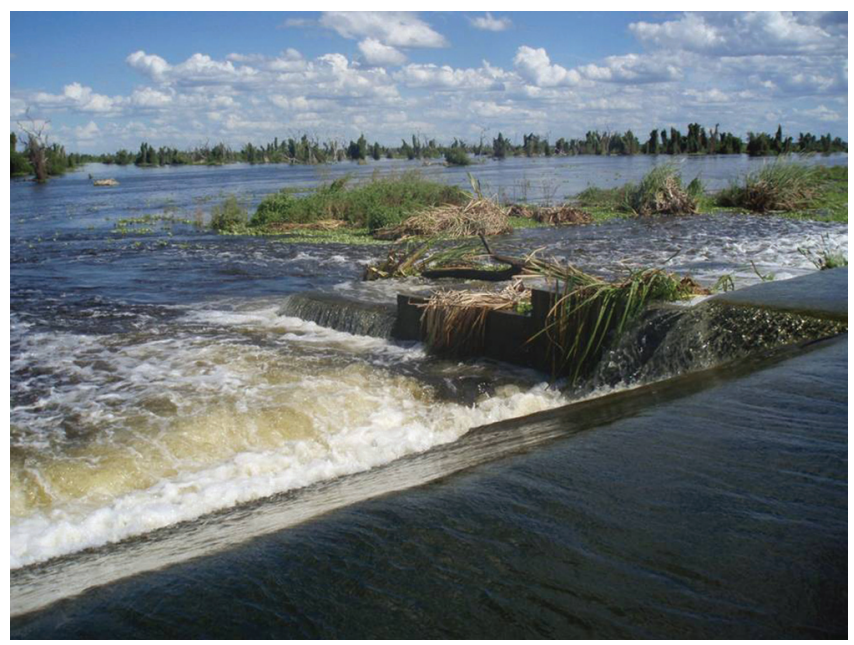

Fig. 6. View of a fish ladder (pool and weir system) operating during high flow conditions showing the contrast between discharge from spillway and attraction flow derived from the fish ladder. Note the debris inside the pools. 
only $2 \%$ of transferred numbers. Agostinho et al. (2007c) concluded that the system selectivity represented a bottleneck for migratory species.

The fish passage system installed at the Route 28 Dam does not follow the general principle advocated by Cowx \& Welcomme (1998). It neither function under different hydrological conditions nor does it release suitable attraction flows. The limitations are, in part, related to the fact that ladders were built directly on the spillway which do not follow basic guidelines for fish passage design. Similar poor performance was noted for Canoas and Dourado dams in Brazil which have the ladder entrances very close to spillways (Martins, 2005).

A major limitation for designing more efficient fishways in South America is the need to obtain a sound knowledge of fish swimming capabilities. Most previous studies have been directed at salmonid swimming characteristics (e.g. Beach, 1984; Zou, 1982; Videler, 1993; Keynard, 1993). Critical velocities have been estimated for non salmonid species inhabiting northern hemisphere (Pavlov, 1989) but swimming capabilities for neotropical species are still scant (de Castro et al., 2010; Santos et al., 2007, 2009). Most neotropical fishes are smaller than salmonids but compensate by displaying higher metabolic rates as they inhabit warmer rivers. Although values reported by Godoy (1985) are probably overestimated, neotropical species may be able to display higher burst speeds than cold water species of the same size. Santos et al. (2007), for example, found higher critical speeds for Leporinus reinhardti compared with salmonids.

Development of swimming speed information for neotropical species require further research to validate if Beach's (1989) model adjusted for salmonid swimming speeds could be applied. Alternative models based solely on fish length not considering temperature effects such as those proposed by Videler (1993) and Wolter \& Arlinghaus (2003) and yield smaller burst speeds. Hydrodynamic cues used by fish to select their swim path during upstream migrations are being recognized as key factors that can determine if fish use or reject a fishway (Nestler et al., 2007). As noted by Baigún et al. (2007) dams are not natural structures in rivers and may create hydrodynamic patterns that are unusual or non-existent in natural rivers that elicit avoidance behaviors by fish. The Route 28 roadbed effectively impounds flow creating a permanently flooded area upstream, but a seasonally dewatered area downstream. Steps can be taken at La Estrella marsh to decrease fish mortality downstream of the dam and improve upstream fish passage efficiency. One method of reducing downstream mortality of adult fish during the dry season is to inhibit their downstream movement during the wet season. We propose that the slope of the upstream embankment of the roadbed be decreased (i.e., flattened) to gradually reduce water depth encountered by fish as they approximate to the dam from upstream. We believe the shallower water will cause fish to be less likely to cross the roadbed, at least during low to moderate flows, but not during very high flows. On the other hand, to encourage upstream fish movement, the existing slope of the spillway needs to be flattened to reduce water velocity at the chute and lessen turbulence in the dissipation pool.
At the main spillway, the most effective and least costly option to restore passage at this site is probably a rock ramp fishway which is usually recommended for low head, wide dams and seasonal hydrologic pattern. These systems are common in many parts of the world (but not in South America) and their design guidelines and proper applications are well known. Typically, a rock ramp exhibits a range of velocities from relatively slow to relatively fast so that passage of many different species is facilitated over a range of discharges. During higher flows, the ramp is largely inundated, but still provides low water velocities at the edges and bottom because of the roughness of the rocks. The only disadvantage of a rock ramp for application to the Route 28 Dam is the possible need to slightly deepen the roadbed immediately upstream of the rock ramp. Also rock ramps become unusable as water levels in the marsh decrease to near the spillway crest because they dewater. These and other accommodations or compromises would have to be determined during engineering design. In addition, we recommend that a short reregulation dam (a smaller dam designed to modify the releases of a larger upstream dam) be constructed at a location where fish concentrate below the spillway. The reregulation dam would be located far enough downstream to prevent dewatering between the spillway and tailwater during the dry season. The reregulation dam would have its own fish entrances and provide sufficient depth for fish to jump into the lowest pool of the fish ladder.

Vertical slot fishways could improve fish passage upstream because they do not dewater as long as the part of the most upstream slot is submerged. Vertical-slot ladders are considered the best technical type of fishway because they allow a large number of species to ascend including small fishes, weak swimmers, and both bottom dwellers and open-water fish. However, installation of such systems would require first a careful analysis of fish distribution according to tailrace water level variations and topography to recognize the most suitable entrance location. In addition, such systems should be supplied with water from the marsh so we recommend installing their exits as close as possible from the spillway upstream to maximize water intake. Duration of use of vertical slot fishways may vary from one to four months according to regional rainfall patterns. This solution represents a tradeoff between water use for productive activities and environmental requirements and fish biological characteristics but is in agreement with a more sustainable water use policy. In turn, the secondary controlled spillway need to be replaced by a regulated bypass system to allow fish passage into La Estrella marsh from the Salado River.

The Route 28 Dam case is a case-history of a technical fishway installed in a lowland river that did not consider standard bioecological requirements to sustain neotropical fishes. These fish exhibit complex life histories that evolved in a highly variable environment as displayed by the Pilcomayo River and associated marshes. Previous studies in the La Plata basin focused primarily on hydropower dams which are by far more visible in terms of size, environmental concerns, and social conflicts. However, low height dams like the Route 28 Dam are very abundant in South America and, based on this study, their impacts on fish can be substantial and, consequently, they should receive increased 
scientific attention. For example, in Brazil, about 200 such small dams are in operation (Martins, 2000) and those few with fishways are generally lower than $10 \mathrm{~m}$ in height (Agostinho et al., 2002).

Construction of efficient fish passes in systems like La Estrella marsh will require a new vision for fish passage that encompasses the application of bioengineering criteria developed specifically for neotropical fishes even in low height dams. For instance, location of new fish passages and their entrances should be decided only after assessing hydrological and hydrodynamic conditions downstream in addition to fish bioecological characteristics. This is critical if additional dams for irrigation or water diversion like the Route 28 Dam will be installed in other basins. Additionally, reliance on salmonid fish passage systems as a template for South American fishes without appropriate adaptations to the requirements of local species has led to poor passage at many South America dams (Baigún et al., 2011). This is not surprising since the life-history patterns of neotropical species differ substantially from that of salmonids (Oldani et al., 2005, 2007). As was shown for this case-history, fish passage designs based on salmonid models are typically not efficient when applied to South American fishes (Agostinho et al., 2002, Oldani et al., 2007) and such failures are found also for other non salmonid species of other world areas (Mallen-Cooper \& Brand, 2007). In any case new systems to be installed in this and other irrigation dams need to be developed based upon knowledge about fish swimming capabilities, fish behavior, regional hydrology, and local flow patterns. The main lesson of this study is that even low head dams less than $1.5-2.0 \mathrm{~m}$ in height can exert significant impacts on migratory fish movements and that construction of even simple fish passage systems without taken into account above considerations represent a risky and costly decision. We emphasize that a robust bioengineering approach that encompasses hydraulic design criteria combined with bioecological information of local fish fauna is required not just for large, high head hydropower dams, but also for the many more lower head smaller dams.

\section{Acknowledgments}

We want to acknowledge Pablo Bronstein for his help with hydrological data analysis.

\section{Literature Cited}

Agostinho, A. A., L., C. Gomes, D. Rodríguez Fernandez \& H. I. Suzuki. 2002. Efficiency of fish ladders for neotropical icthyofauna. River Research and Application, 18: 299-306.

Agostinho, A. A., L. C. Gomez, H. I. Susuki \& H. F. Julio Jr. 2003. Migratory fishes of the Paraguay-Paraná basin, Brazil. In: Carolsfeeld, J., B. Harvey, C. Ross \& A. Baer (Eds.). Migratory fishes of South America. Biology, fisheries and conservation status. World Fisheries Trust/World Bank/IDRC 2004: 19-99.

Agostinho, A. A., L. C. Gomes \& J. D. Latini. 2004. Fisheries management in Brazilian reservoirs: lessons from South America. Interciencia, 29: 334-338.

Agostinho, C. S., C. R. Pereira, R. J. de Oliveira, I. S. Freitas \& E. E. Marques. 2007a. Movements through a fish ladder: tempo- ral patterns and motivations to move upstream. Neotropical Ichthyology, 5: 161-167.

Agostinho, A. A., L. C. Gomes \& F. M. Pelicice. 2007b. Ecologia e manejo de recursos pesqueiros em reservatórios do Brasil. Ed. Universidade Estadual de Maringa, EDUEM, 512p.

Agostinho, A. A., E. E. Marques, C. S. Agostinho, D. A. de Almeida, R. J. De Oliveira \& J. R. Bezerra de Melo. 2007c. Fish ladder of Lajeado Dam: migrations on one-way routes? Neotropical Ichthyology, 5: 121-136.

Agostinho, C. S., A. A. Agostinho, F. Pelicice, D. A. de Almeida \& E. E. Marques. 2007d. Selectivity of fish ladders: a bottleneck in neotropical fish movement. Neotropical Ichthyology, 5: 205-213.

Alves, C. B. 2007. Evaluation of fish passage through the Igarapé Dam fish ladder (rio Paraopeba, Brazil), using marking and recapture. Neotropical Icthyiology, 5: 233-236.

Baigún, C. R., J. M. Nestler, N. O. Oldani, R. A. Goodwin \& L. J. Weber. 2007. Can North American fish passage tools work for South American migratory fishes? Neotropical Ichthyology, 5: 109-119.

Baigún, C., N. Oldani \& P. Van Damme. 2011. Represas hidroeléctricas en América Latina y su impacto sobre la ictiofauna. Pp. 397-416. In: Van Damme, P. A., F. Carvajal \& J. Molina (Eds.). Peces de la Amazonía boliviana: potencialidades y amenazas. Ed. Inia, Cochabamba, Bolivia, 490p.

Bayley, P. 1973. Studies on the migratory characin Prochilodus platensis Holmberg 1888 (Pisces, Characoidei) in the river Pilcomayo, South America. Journal of Fish Biology, 5: 25-40.

Beach, M. H. 1984. Fish passes design. Criteria for the design and approval of fish passes and other structures to facilities the passage of migratory fishes in rivers. Fisheries Resource Technical Reports No. 78. Ministry of Agriculture, Fisheries and Food, Lowestoft, 46p.

Beamish, F. W. 1978. Swimming capacity. Pp. 101-187. In: Hoar, W. S. \& J. D. Randall (Eds.). Fish Physiology, vol. 7. Academic Press Inc., New York, 576p.

Bjornn, T. C. \& D. W. Reiser. 1991. Habitat requirements of salmonids in streams. Pp. 83-138. In: Meehan W. (Ed.). Influences of forest and rangeland management on salmonid fishes and their habitats. American Fisheries Society Special Publication 19, Bethesda, Maryland, 751p.

Bonetto, A. A., C. Pignalberi, E. Cordiviola de Yuan \& O. Oliveros, 1971. Informaciones complementarias sobre migraciones de peces en la cuenca del Plata. Physis, 30: 505-520.

Bonetto, A. A., M. Canon Verón \& D. Roldán. 1981. Nuevos aportes al conocimiento de las migraciones de peces en el río Paraná. Ecosur, 16: 29-40.

Britto, S. G. C. \& R. N. Sirol. 2005. Transposição de peixes como forma de manejo: as escadas do Complexo Canoas, médio rio Paranapanema, bacia do Alto Rio Paraná. Pp. 285-304. In: Nogueira, M. G., R. Henry \& A. Jorcin (Eds.). Ecologia de Reservatórios: Impactos Potenciais, Ações de Manejo e Sistemas em Cascata. São Carlos, Rima.

Capeleti, A. R. \& M. Petrere Jr. 2006. Migration of the curimbata Prochilodus lineatus (Valenciennes, 1836) (Pisces Prochilodontidae) at the waterfall "Cachoeira de Emas" of the Mogi-Guaçu river, São Paulo, Brazil. Brazilian Journal of Fish Biology, 66: 651-659.

Clay, C. 1995. Design of fishways and other fish facilities. CRC Press Boca Raton, Florida, 247p.

Cowx, I. \& R. L. Welcomme (Eds.). 1998. Rehabilitation of rivers for fish. FAO and Fishing New Books, Blackwell Science, Ltd, Oxford, UK, 204p.

de Castro, M., H. dos Santos, F. A. Sampaio \& P. Pompeu. 2010. Swimming performance of the small characin Bryconamericus 
stramineus (Characiformes: Characidae). Zoologia, 27: 939-944.

Delfino, R., C. Baigún \& R. Quirós. 1986. Esclusas de peces en la represa de Salto Grande. Consideraciones acerca de su funcionamiento. Informes Técnicos del Departamento de Aguas Continentales No. 4, INIDEP, Mar del Plata, 55p.

Fernandez, D. R., A. A. Agostinho \& L. M. Bini. 2004. Selection of an experimental fish ladder located at the dam of the Itaipu Binacional, Paraná River, Brazil. Brazilian Archives of Biology and Technology, 47: 579-586.

Ginzburg, R., J. Adámoli, P. Herrera \& S. Torella. 2005. Los humedales del Chaco; Clasificación, inventario y mapeo a escala regional. Pp. 121-138. In: Aceñolaza, F. (Ed.). Temas de la Biodiversidad del Litoral Fluvial Argentino II. INSUGEO, Miscelánea 14, 550p.

Godinho, H. P., A. L. Godinho, P. S. Formagio \& V. C. Torquato. 1991. Fish ladder efficiency in a southeastern Brazilian river. Ciência e Cultura, 43: 63-67.

Godoy, M. P. 1975. Peixes do Brazil sub-ordem Characoidei - Bacia do rio Moji-Guassú. Pp 629-847. Vol IV/VIII. Ed. Franciscana, Piracicaba, S. P.

Godoy, M. P. 1985. Aquicultura. Atividade multidisciplinar. Escadas e outras facilidades para passagens de peixes. Estações de Piscicultura. Electrosul-Electrobras, 77p.

Katopodis, C. 1992. Introduction to fishway design. Working Document, Freshwater Institute, Fisheries and Oceans Canada, Winnipeg, Manitoba, 67p.

Larinier, M. 2001. Environmental issues, dams and fish migrations. Pp. 45-90. In: G. Marmulla (Ed.). Dams, fish and fisheries. Opportunities, challenges and conflict resolution. FAO Fisheries Technical Paper Nro 419, 166p.

Larinier, M. 2002a. Fishways: general considerations. Pp. 21-27. In: Larinier, M., F. Travade \& J. P. Porcher (Eds.). Fishways; biological basis, design criteria and monitoring. Bulletin Français de la Pêche et de la Pisciulture, 364 suppl., 207p.

Larinier, M. 2002b. Location of fishways. Pp. 39-53. In: Larinier, M., F. Travade \& J. P. Porcher (Eds). Fishways; biological basis, design criteria and monitoring. Bulletin Français de la Pêche et de la Pisciulture, 364 suppl., 207p.

Larinier, M. 2002c. Pool fishways, pre-barrages and natural bypass channels. Pp. 54-82. In: Larinier, M., F. Travade \& J. P. Porcher (Eds.). Fishways; biological basis, design criteria and monitoring. Bulletin Français de la Pêche et de la Pisciulture, 364 suppl., 207p.

Larinier, M. 2002d. Biological factors to be taken into account in the design of fishways, the concept of obstructions to upstream migration. Pp. 28-38. In: Larinier, M., F. Travade \& J. P. Porcher (Eds.). Fishways; biological basis, design criteria and monitoring. Bulletin Français de la Pêche et de la Pisciulture, 364 suppl., 207p.

Makrakis, S., L. C. Gomes, M. C. Makrakis, D. R. Fernandez \& C. S. Pavanelli. 2007. The canal da Piracema at Itaipu Dam as a fish pass system. Neotropical Icthyology, 5: 185-195.

Mallen-Cooper, M. \& D. A. Brand. 2007. Non-salmonids in a salmonid fishway: what do 50 years of data tell us about past and future fish passage? Fisheries Management and Ecology 14: 319-332.

Martins, S. L. 2000. Sistemas para transposição de peixes. Unpublished Tesis di Maestria Universidades de São Paulo, 184p.

Martins, S. L. 2005. Sistema para a a transposição de peixes neotropicais potadromos. Unpublished P.h. Dissertation, Universidade de São Paulo, São Paulo, 400p.

Motchek, A., K. Dzerkinskii, D. Pavlov \& A. Torres. 1995. Proyecto estudio ecológico del sábalo del río Pilcomayo. Informe anual 1995. Convenio CODETAR-Academia de Ciencias de Rusia, 90p.

Nestler, J. M., C. R. Baigún, N. O. Oldani \& L. J. Weber. 2007.
Contrasting the Middle Paraná and Mississippi Rivers to develop a template for restoring large floodplain river ecosystems. Journal of River and Basin Management, 5: 305-319.

Oldani, N. \& C. Baigún. 2002. Performance of a fishway system in a major South American dam on the Parana River (ArgentinaParaguay). River Research and Applications, 18: 171-183.

Oldani, N.O., C. Baigún \& R. Delfino. 2005. Consideraciones sobre los sistemas de transferencia para peces en las represas de los grandes ríos de la cuenca del Plata en la Argentina. Pp. 360-381. In: F. G. Aceñolaza (Coord.). Temas de la biodiversidad del litoral fluvial argentino II. INSUGEO, Misceláneas 14, 550p.

Oldani, N. O., C. R. M. Baigún, J. M. Nestler \& R. A. Goodwin. 2007. Is fish passage technology saving fish resources in the lower La Plata River basin? Neotropical Ichthyology, 5: 89-102.

Pavlov, D. S. 1989. Structures assisting the migrations of nonsalmonid fish. USSR, FAO Fisheries Technical Paper 308. Food and Agriculture Organization of the United Nations Rome, 97p.

Powers , P. D. \& J. F. Orsborn. 1985. Analysis of barriers to upstream fish migration: An investigation of the physical conditions affecting fish passage success at culverts and waterfalls. Final Report 1984 (Project No. 82-14). Portland, OR: U.S. Department of Energy, Bonneville Power Administration, Division of Fish and Wildlife. xiii+120 pp. Available from http://www.efw.bpa.gov/Publications/ U36523-1.pdf (Date of access: June 2012)

Quirós, R. 1989. Structures assisting the migrations of non salmonis fish: Latin America. COPESCAL Technical Paper No5, FAO. Rome, $41 \mathrm{p}$.

Quirós, R. 2004. The La Plata river basin: International basin development and riverine fisheries. Pp. 253-272. In: Welcomme, R. \& T. Petry (Eds.). FAO Regional Office for Asia and the Pacific, Bankok, Thailand, RAP Publication 2004/15. Proceedings of the second international symposium on the management of large rivers for fisheries. Volume I, 357p.

Reiser, D. W., C. Huang, S. Beck, M. Gagner \& E. Jeanes. 2006. Defining flow windows for upstream passage of adult anadromous salmonids at cascades and falls. Transactions of the American Fisheries Society, 135: 668-679.

Smolders, A. J., G. van der Velde, G. Roelof \& M. A. Guerrero Hiza. 2000. El Niño caused collapse of the sabalo fishery (Prochilodus lineatus, Pisces: Prochilodontidae) in a South American river. Natürwissenschaften, 87: 30-32.

Santos, H., P. Pompeu \& C. B. Martinez. 2007. Swimming performance of the migratory neotropical fish Leporinus reinhardti (Characiformes: Anostomidae). Neotropical Ichthyology, 5: 139-146.

Santos, H., P. Pompeu, G. S. Vicentini \& C. B. Martinez. 2009. Swimming performance of the migratory neotropical fish Pimelodus maculatus Lacépéde 1830. Brazilian Journal of Biology, 68: 433-439.

Videler, J. 1993. Fish swimming. Chapman \& Hall, Fish and Fisheries Series 10, 260p.

Webb, P. W. 1984. Form and function in fish swimming. Scientific American, 251: 157-165.

Wolter, C. \& R. Arlinghaus. 2003. Navigation impacts on freshwater fish assemblages. The ecological relevance of swimming performance. Reviews in Fish Biology and Fisheries, 13: 63-89.

Zhou, Y. 1982. The swimming speed of fish in towed gears, a reexamination of the principles. Department of Agriculture and Fisheries for Scotland, Working Paper 4, 55p.

Submitted March 21, 2012 Accepted August 19, 2012 